ЛЮЛЬЧУК Н.М.

\title{
ЩОДО ІСТОРИЧНОЇ ГЕНЕЗИ ІНСТИТУТУ ПРАВНИЧОЇ ДОПОМОГИ В УКРАЇНІ
}

У статті досліджується історична генеза інституту правничої допомоги в Україні, а також засади правового регулювання надання правничої допомоги в Україні, зокрема у їхньому історичному аспекті. 3'ясовано, що надання правничої допомоги на території України, що перебувала під владою Російської імперії, набуло юридичного оформлення за Судовими Статутами від 20 листопада 1864 року. Зокрема, після проведення судової реформи 1864 року розпочала свою діяльність адвокатура, на яку, власне, і покладалося виконання функцій із надання професійної правничої допомоги. Визначено, що остаточно надання правничої допомоги на території України, що перебувала під владою Російської імперії, набуло юридичного оформлення за Судовими Статутами від 20 листопада 1864 року. Наголошено, що на території України, що перебувала під юрисдикцією Польщі в Українському Горожанському Комітеті, у 1918 році було створено секцію з надання правничої допомоги особам української національної приналежності, які були заарештовані, інтерновані або полонені, а згодом - створено так звану Колегію оборонців, яка об'єднала всіх адвокатів Західної України для надання правничої допомоги українському населенню. Зроблено висновок, що становлення та розвиток інститут правничої допомоги в Україні має давню історію. При цьому можуть бути виділені такі історичні етапи становлення інституту правничої допомоги в Україні: 1 етап - давньоруський період історії України; 2 етап - період перебування території України під владою інших держав; 3 етап - радянський період історії України; 4 етап період становлення і розвитку незалежної Української державності; 5 етап - період демократичного реформування в Українській державі. Тривалість другого та третього етапів для Західної України та іншої території України не $\epsilon$ однаковою. В аспекті розвитку цивільно-правового регулювання надання правничої допомоги відповідні історичні етапи становлення інституту правничої допомоги відповідають стадіям позадоговірного (1 етап) і договірного (2-5 етап) регулювання надання правничої допомоги.

Ключові слова: правнича допомога, представництво, адвокат, адвокатура, договір про надання правничої допомоги.

The article dedicated to historical genesis of the institute of legal aid in Ukraine, and also the ambush of the legal regulation of the provision of legal assistance in Ukraine, with its historical aspect. It has been established that the provision of legal aid in the territory of Ukraine, which was under the rule of the Russian Empire, has become legal in accordance with the Judicial Statutes of November 20, 1864. In particular, after the judicial reform of 1864, the Bar started its activity, which, in fact, was entrusted with performing the functions of providing professional legal assistance. It has been determined that the legal aid in the territory of Ukraine, which was under the rule of the Russian Empire, was finally acquired under the judicial statutes of November 20, 1864. It was emphasized that in Ukraine, under the jurisdiction of Poland in the Ukrainian Civic Committee in 1918, a section was created to provide legal assistance to persons of Ukrainian nationality who were arrested, interned or captured, and subsequently - the so-called "Defenders' Collegium" was created. united all Western Ukraine lawyers to provide legal assistance to the Ukrainian population. It is concluded that the establishment and development of the Legal Aid Institute in Ukraine has a long history. At the same

( ) ЛЮЛЬЧУК Н.М. - аспірант кафедри цивільного права і процесу (Національна академія внутрішніх справ) 
time, the following historical stages of the formation of the Legal Aid Institute in Ukraine can be distinguished: Stage 1 - the Old Russian period of Ukrainian history; Stage 2 - the period of stay of the territory of Ukraine under the authority of other states; Stage 3 - Soviet period of Ukrainian history; Stage 4 - the period of formation and development of independent Ukrainian statehood; Stage 5 is a period of democratic reform in the Ukrainian state. The duration of the second and third stages is not the same for Western Ukraine and other territories of Ukraine. In terms of the development of civil law regulation of legal aid, the relevant historical stages of becoming an institution of legal aid correspond to the stages of out-of-contract (phase 1) and contractual (2-5 stages) regulation of legal aid.

Key words: legal aid, representation, lawyer, advocacy, legal aid agreement.

Вступ. Розвиток інституту правничої допомоги Україні має давню історію, і його генеза вже тривалий час становить предмет наукового інтересу вчених - істориків та правників. Водночас в умовах динамічного реформування інституту правничої допомоги в Україні навряд чи можна вважати відповідну проблематику вичерпаною, адже історичний досвід минулого становить підгрунтя майбутнього розвитку для всіх правових явищ.

Стан дослідження. Дослідженню питань розвитку інституту правничої допомоги приділялася увага в наукових працях С. Борисенка, В. Брехуненка, Є. Васьковського, I. Гловацького, А. Джуської, В. Личко, В. Попелюшка, О. Святоцького, І. Синяка, А. Титова, Г. Токунової, О. Філонова, В. Шкарупи та інших дослідників. Утім, незважаючи на те, що дослідженню питань реалізації права на правничу допомогу було присвячену значну кількість наукових праць вітчизняних та зарубіжних вчених, слід констатувати, що увагу науковців привертали передусім конституційно-правові та процесуальні аспекти правничої допомоги, натомість засади правового регулювання ії надання, в тому числі у їхньому історичному аспекті, наразі досліджені недостатньо.

Постановка завдання. Мета статті полягає в дослідженні історичної генези інституту правничої допомоги та засад правового регулювання надання правничої допомоги в Україні, зокрема й у їхньому історичному аспекті.

Результати дослідження. Історія становлення й розвитку інституту надання правничої допомоги в Україні тісно пов'язана з розвитком інституту судового представництва, який бере свій початок що від часів Давньої Русі. Зокрема, арабський дослідник арабський дослідник X століття Ібн-Руста (Ібн-Даста) зауважує, що у слов'ян ще в IX столітті існував інститут судового представництва й захисту прав інших осіб, зазначаючи щодо можливості родичів допомагати учасникам спору, виступати правозаступниками й представниками на суді нарівні зі стороною [1, с. 21], що ставить під сумнів твердження щодо існування на той час беззаперечного принципу «особистої явки», який не допускав існування судового представництва [2; 3, с. 14]. Натомість відсутність конкретних норм щодо судового представництва в тексті таких стародавніх правових пам'яток, як «Руська правда», може зумовлюватись, зокрема, загальним звичаєвим характером права того часу, внаслідок чого письмовий закон міг не передбачувати багатьох важливих моментів [2]. Слід також враховувати, що в давньоруські часи функції захисту, обвинувачення та покарання виконували общини та їхні органи управління [4, с. 610], тоді як соціальний інститут суду з'явився дещо пізніше. Утім, вже на цьому етапі започатковувалась певна «процесуальна» регламентація - роль захисників могли виконувати родичі, друзі та сусіди сторін, а також особи, що залучалися як свідки добропорядного життя сторін або ж свідки спірного факту [5, с. 32]. При цьому «послухами» не могли виступати холопи і закупи, а також деякі інші категорії членів громад [6, с. $11-12 ; 7$, с. $38-41]$.

Уперше про судове представництво як самостійний правовий інститут на давньоруських територіях згадується у Псковській та Новгородській судних грамотах XV століття. Так, за ст. 58 Псковської судної грамоти було заборонено участь родичів та сусідів у суді, а також було передбачено, що старі й глухі люди, монахи, жінки й діти мали право мати в суді представника (тобто мова йде про осіб, які внаслідок фізичного обмеження можливостей або за звичаєм не могли брати участь у суді особисто). При цьому ст. 71 Псковської грамоти забороняла ведення одним представником більше двох справ за один день, а також встановлювала відповідальність для осіб, які бажали «допомагати» у суді в порушення встановленої процедури. У справах про землі, що належать церкві, повіреними могли виступати тільки церковні старости (ст. 70). Псковська судна грамота також встановлювала заборону бути повіреними тим, хто був наділений владою, за винят- 
ком випадків, коли посадова особа, наділена владою, виступала за себе особисто або як церковний староста (ст. 68, ст. 69) [4, с. 623]. За Новгородською судною грамотою (ст. ст. 5, 15, 18, 19, 32) право мати представників у суді - повірених - надавалося кожній особі [4, с. 615], водночас за наявності повіреного сторони повинні були взаємодіяти тільки через нього, тобто мало місце процесуальне заміщення сторони представником (ст. 5) [8]. Судове представництво на той час існувало у двох формах: природній і найманій. Надалі інститут найманих представників поступово перетворився на інститут професійних повірених - ходатаїв у справах та стряпчих $[6$, с. $13 ; 9$, с. 16]. Також слід зауважити, що, незважаючи на те, процес за Псковською і Новгородською судними грамотами у цілому мав обвинувальний ухил, він не поділявся на кримінальний та цивільний процеси. Тобто слід констатувати, що участь представників допускалася як у кримінальних, так і у цивільних справах.

Надалі в давньоруських землях, у тому числі й на Українських територіях, що відійшли до Московського князівства, становлення інституту судового представництва відбувалося в рамках Судібників 1497 та 1550 років. Натомість на території Литовсько-Руської держави, до якої входила частина земель сучасної України, перші ознаки формування інституту судових представників можуть бути знайдені ще в письмових джерелах права XIII століття, зокрема в Литовській Метриці згадуються судові представники під назвами «посол» і «прокуратор» [9, с. 88-95; 19, с. 34; 11, c. 93-105].

Питання надання правничої допомоги найбільш детально висвітлювалось у статутах Великого Князівства Литовського $1529,1566,1588$ років, дія яких поширювалася на територію України. Зокрема, ст. 10 Статуту 1529 року встановлювала обмеження для іноземців виступати як прокуратор (адвокат) у суді [12, с. 34-35]. Статут 1588 року, який базувався на «Руській правді» та засадах магдебургського права, вже безпосередньо передбачав, що прокуратор мав право виступати в суді як представник однієї зі сторін або її помічник. Цей Статут також запроваджував інститут спеціального урядового захисник для вдів і сиріт, які не могли захищати себе особисто [10, с. 16-18]. Статут 1588 року (відомий також як Третій Литовський Статут) також визначав коло професійних прав та обов'язків представника (прокуратора), а також закріплював принципи професійної діяльності представника та певні норми щодо представницької етики [11, с. 90-98; 13, с. 10]. Також Статут висував низку вимог до особи, яка здійснювала професійне представництво в суді (вільна людина незалежно від походження, окрім духовенства та персоналу замкових і земських судів у підвідомчих округах $[11 ; 14$, с. 4]). Отже, в нормах Литовських Статутів, які продовжували діяти і в добу Гетьманщини (1628 рік - кінець XVIII століття ) [5, с. 34], вперше в історії Україні було здійснено спробу впорядкувати питання судового представництва, започаткувавши таким чином становлення інституту правничої допомоги в Україні.

Із приводу досліджень наступного історичного періоду становлення інституту правничої допомоги в Україні слід зауважити, що 5 серпня 2017 р. було презентовано історичну монографію В. Брехуненка та I. Синяка «Адвокати у судочинстві ранньомодерної держави Гетьманщини», автори якої довели, що в період Гетьманщини на території України було впроваджено надання професійної правничої допомоги та існувала змагальність судового процесу. Зокрема, в монографії було проаналізовано історичну генезу адвокатури як спеціального соціального інституту, діяльність якого спрямовувалась на надання правничої допомоги, з'ясовано законодавче поле діяльності адвокатів, досліджено роль професійного представника у судовому процесі Гетьманщини тощо. Дослідникам вдалося встановити 135 правників того часу, зокрема тих, які представляли в судах інтереси гетьманів К. Розумовського, П. Полуботка, а також інтереси Михайлівського золотоверхого монастиря, Софії Київської, Києво-Печерської Лаври тощо [15].

У XVIII столітті на території України, яка перебувала у складі Російської імперії, питання надання правничої допомоги регулювалися на підставі проекту своєрідного українського процесуального кодексу, який мав назву «Права, за якими судиться малоросійський народ». Зокрема, передбачалася участь у судах професійних юристів - прокураторів або речників. При цьому надавати професійну правничу допомогу могли: чоловіки, розумово й фізично здорові, повнолітні, християни, світського походження. Для осіб, які не могли себе захищати самостійно, призначався урядовий захисник. У цілому правнича допомога надавалась на платних засадах, втім передбачалося її безоплатне надання для малозабезпечених, удів та сиріт [5, с. 34-35]. У цьому проекті «кодексу» українського права вперше було вжито терміни «адвокат», «повірений» тощо [6, с. 12]. Незважаючи на те, що проект офіційно не набув чинності, «Права, за якими судиться малоросійський народ», використовувались на території України до середини XIX століття $[16 ; 17]$.

Остаточно надання правничої допомоги на території України, що перебувала під владою Російської імперії, набуло юридичного оформлення за Судовими Статутами від 20 листопада 
1864 року. Зокрема, після проведення судової реформи 1864 року розпочала свою діяльність адвокатура, на яку, власне, і покладалося виконання функцій з надання професійної правничої допомоги. Судові статути передбачали діяльність присяжних повірених, що здійснювали захист на професійній основі, та приватних повірених, які індивідуально займалися відповідною практикою $[14$, с. 7$]$. Також було закладено засади регулювання правовідносин із надання правничої допомоги.

Зазначимо, що в Російській імперії кожні три роки міністром юстиції, за поданням судових палат і Рад присяжних повірених, установлювався розмір «такси» за надання правничої допомоги. М. Кожевніков відзначає, що «якщо звернутися до такси оплати адвокатів по цивільних справах, що діяла у царській Росії, то з неї видно, що в основу визначення розміру винагороди були покладена: 1) сума позову й 2) результат розгляду справи в суді» [18, с. 15]. Докладно висвітлює підходи до визначення розміру винагороди того періоду й Л. Грудцина, приходячи до висновку, що основним критерієм під час визначення розміру гонорару за надання правничої допомоги у цивільних справах була ціна позову [19]. Згідно зі ст. 395 Судових Статутів 1864 року розмір і порядок виплати винагороди повіреному визначалися письмовою угодою 3 довірителем, що підтверджує застосування до питань регулювання надання правничої допомоги положень цивільного права. На договірних засадах правнича допомога на території України, що перебувала під владою Російської імперії, надавалася до 1917 року [6, с. 14; 20].

3 установленням радянської влади на територію України було поширено дію радянського законодавства, яке істотно реформувало систему надання правничої допомоги. Так, ст. 3 Декрету про Суд №1 1917 року передбачала, що правнича допомога не обов’язково може бути професійною, адже захисниками у справі на стадії попереднього слідства могли бути громадяни чоловічої та жіночої статі з бездоганною репутацією, наділені цивільними правами [5, с. 40]. У 1918 році при Радах робітничих і селянських депутатів були засновані колегії захисників, обвинувачів і представників сторін у цивільному процесі [6, с. 15], а також запроваджено інститут «загальногромадянського обвинувачення і захисту» [5, с. 40-41]. Зауважимо, що у 1918-1922 роках праця членів колегій захисників фактично прирівнювався до праці державного службовця. Як зазначає В. Буробін, «члени цих колегій ставали (...) державними службовцями на окладі, розмір якого прирівнювався до окладів суддів народних судів. Довірителі повинні були вносити плату за послуги адвоката на рахунок Комісаріату юстиції, з його бюджету сплачувалася заробітна плата» $[21$, c. 45$]$.

У 1922 році було прийняте Положення про адвокатуру Української Радянської Соціалістичної Республіки (далі - УРСР), а також затверджено Інструкцію про організацію губернських колегій захисників при губернських районних народних судах та Положення про консультації для надання юридичної допомоги населенню, що організовуються колегіями захисників [22, с. 15]. Базове Положення про адвокатури від 26 травня 1922 року встановлювало, що, за загальним правилом, розмір винагороди за надання правничої допомоги визначався за згодою сторін. У той же час робітники державних і приватних підприємств, а також службовці радянських установ мали право оплачувати послуги захисників за таксою, установлюваною Народним комісаріатом юстиції (у цивільних справах - не більш 5\% від присудженої суми, тоді як у кримінальних справах таксою передбачався лише межа гонорару, яка визначалася президією колегії «залежно від розміру й складності справи»). Що стосується осіб, визнаних постановою народного суду незаможними, то вони звільнялися від оплати наданої правничої допомоги [23].

У 1928 році робота членів колегій захисників була переведена на колективні форми організації, а приватна практика надання правничої допомоги - припинена [5, с. 45-46; 7, с. 45; 24].

Згідно з Положенням про адвокатури СРСР 1939 року розмір винагороди адвоката повністю залежав від такси, а можливість регулювання розміру гонорару за надання правничої допомоги угодою сторін не передбачалася [25].

На початку Другої Світової війни листом Народного комісаріату юстиції від 25 грудня 1941 року «Про призначення захисту на вимогу судів» було встановлено порядок виділення адвокатів для захисту обвинувачених у справах, що розглядалися військовими трибуналами і загальними судами, а також розширено перелік послуг з надання безоплатної правничої допомоги адвокатськими колегіями $[5$, с. $47 ; 12$, с. 45$]$.

Щодо Західноукраїнських земель слід зазначити, що на території Австро-Угорської імпеpiï у другій половині XIX - на початку XX століття правнича допомога надавалася на професійних засадах [22, с. 13]. Зокрема, на території України, що перебувала під юрисдикцією Польщі в Українському Горожанському Комітеті, у 1918 році було створено секцію з надання правничої до- 
помоги особам української національної приналежності, які були заарештовані, інтерновані або полонені, а згодом - створено так звану Колегію оборонців, яка об'єднала всіх адвокатів Західної України для надання правничої допомоги українському населенню [7, с. 42-43].

Важливими віхами розвитку інституту надання правничої допомоги в Україні у повоєнний період часу стало прийняття Верховною Радою УРСР у 1960 році Закону про судоустрій УРСР [26] та Кримінального-процесуального кодексу [27], а також Цивільного процесуального кодексу у 1963 році [28].

Постанова Ради Міністрів УРСР від 8 грудня 1965 року №1178 «Про затвердження Положення про оплату праці адвокатів в Українській РСР та Інструкції про порядок оплати юридичної допомоги, яка надається адвокатами громадянам, підприємствам, установам, радгоспам, колгоспам та іншим організаціям Української РСР» передбачала, що: угода про характер і обсяг прийнятого юридичною консультацією доручення, а також про розмір плати за юридичну допомогу та інші витрати, зв'язані з виконанням доручення, витрати на відрядження тощо, заноситься до реєстраційної картки, яка підписується завідувачем юридичної консультації, адвокатом і особою, що звернулась за допомогою (п. 2); для подання юридичної допомоги підприємствам, установам, радгоспам, колгоспам та іншим організаціям юридичні консультації укладають із ними договори з оплатою погодинно або за разовими дорученнями (п. 23) [29].

Конституція УРСР 1978 року у ст.156 передбачала, що обвинуваченому забезпечується право на захист, а у ст. 159 - функціонування адвокатур для надання юридичної допомоги «громадянам і організаціям» [30].

П. 2 ч. 2 ст. 21 Положення про адвокатуру УРСР від 31 жовтня 1980 року [31] передбачав, що завідуючий юридичною консультацією «укладає угоди із громадянами про подання юридичної допомоги і договори з підприємствами, установами і організаціями на юридичне обслуговування», тобто безпосередньо визначалося, що на відносини з надання правничої допомоги поширюються положення цивільного права.

Із проголошенням у 1991 році незалежності України розпочався новий етап у розвитку інституту надання правничої допомоги. Зокрема, 19 грудня 1992 року було прийнято Закон України «Про адвокатуру» [32], ст. 12 якого передбачала, що оплата праці адвоката здійснюється на підставі угоди між громадянином чи юридичною особою і адвокатським об'єднанням чи адвокатом. 28 червня 1996 року було прийнято нову Конституцію України, відповідно до ст. 59 якої кожному гарантувалося право на правову допомогу, зокрема й безоплатну у випадках, передбачених законом [33].

У 2011 році було прийнято Закон України «Про безоплатну правову допомогу» [34], після чого розпорядженням Кабінету Міністрів України від 4 липня 2012 року № 435-р [35], а надалі й постановою Кабінету Міністрів України від 13 лютого 2013 року № 394 [36] було затверджено Державну цільову програму формування системи безоплатної правової допомоги на 2013-2017 роки, якою передбачалося розроблення та здійснення комплексу заходів правового, організаційного та економічного характеру, спрямованих на забезпечення доступу до безоплатної правової допомоги осіб, які мають на неї конституційне право і потребують такої допомоги.

У 2012 році було прийнято Закон України «Про адвокатуру та адвокатську діяльність» [37], яким також закріплювались сучасні засади правового регулювання надання правничої допомоги. Зокрема, норми вказаних законів передбачають договірні відносини щодо надання правничої допомоги, а також створюють підстави для застосування до таких відносин цивільно-правових норм, що регулюють надання послуг (детальніше про це далі).

У 2016 році Законом України «Про внесення змін до Конституції України (щодо правосуддя)» [38] було змінено ст. 59 Конституції України, яка сьогодні сформульована таким чином: «Кожен має право на професійну правничу допомогу. У випадках, передбачених законом, ця допомога надається безоплатно. Кожен $є$ вільним у виборі захисника своїх прав» [33] (зауважимо, що до внесення до Конституції України відповідних змін Конституційним судом України неодноразово висловлювалася позиція щодо можливості надання правничої допомоги будь-яким компетентним правником, якого вільно обирає особа, яка потребує правничої допомоги [39-41]). Вказаним Законом Конституцію України було доповнено також ст. $131^{2}$, в якій зазначається, що «тільки адвокат здійснює представництво іншої особи в суді, а також захист від кримінального обвинувачення». При цьому передбачено застереження, що законом можуть бути визначені винятки щодо представництва в суді у трудових спорах, спорах щодо захисту соціальних прав, щодо виборів i peферендумів, у малозначних спорах, а також щодо представництва малолітніх або неповнолітніх осіб та осіб, визнаних судом недієздатними або дієздатність яких обмежена (перехідними 
положеннями до конституційних змін передбачене також поетапне запровадження виключного адвокатського представництва в суді). 32017 року набули чинності зміни і до процесуального законодавства України [42], які, серед іншого, передбачають введення до обігу закріпленого в Конституції України поняття «правнича допомога». При цьому аналіз норм чинного законодавства України дозволяє дійти висновку, що правнича допомога - це складне поняття, яке включає в себе різні види правничих послуг, і дістає прояву в різних формах, в тому числі як професійна правнича допомога.

Висновки. Отже, за результатами проведеного дослідження слід дійти висновків, що становлення та розвиток інститут правничої допомоги в Україні має давню історію. При цьому можуть бути виділені такі історичні етапи становлення інституту правничої допомоги в Україні: 1 етап давньоруський період історії України; 2 етап - період перебування території України під владою інших держав; 3 етап - радянський період історії України; 4 етап - період становлення і розвитку незалежної Української державності; 5 етап - період демократичного реформування в Українській державі. Тривалість другого та третього етапів для Західної України та іншої території України не $\epsilon$ однаковою. В аспекті розвитку цивільно-правового регулювання надання правничої допомоги відповідні історичні етапи становлення інституту правничої допомоги відповідають стадіям позадоговірного (1 етап) і договірного (2-5 етап) регулювання надання правничої допомоги.

Сьогодні Конституція України гарантує саме право на професійну правничу допомогу, під яким слід розуміти гарантовану державою можливість особи отримати високоякісні правничі послуги, які може забезпечити лише професійний адвокат, який пройшов фахову підготовку. Утім, допускаються визначені законом винятки із цього загального правила.

\section{Список використаних джерел:}

1. Васьковский Е.В. Организация адвокатуры. Очерк всеобщей истории адвокатуры. Санкт-Петербург, 1893. Ч. 1. 621 с.

2. Токунова Г.А. Возникновение института судебного представительства и правозаступничества в Древней Руси). URL : http://www.tokunova.ru/publikacii/ kursovaya_istoriya_advokatury rossii/ vozniknovenie instituta_sudebnogo_predstavitelstva_i_pravozastupnichestva_v_drevnej_rusi/ (дата звернення: 12.0̄04.2019).

3. Гаврилов С.Н. История адвокатуры в России: генезис и эволюция форм правозаступничества и судебного представительства (XV - начало XX веков) : монография. Череповец, 2009. 349 с.

4. Обзоръ исторіи русскаго права / проф. М.Ф. Владимірский-Буданов. 6-е изд. С.-Петербургъ, Киевъ : Издание книгопродавца Н.Я. Оглоблина, 1909. 700 с.

5. Шкарупа В.К., Філонов О.В., Титов А.М., Кінаш Ю.Я. Адвокатура України: навч. посіб. / за ред. В.К. Шкарупи. 2-ге вид., випр. Київ : Знання, 2008. 398 с.

6. Сафулько С.Ф., Святоцький О.Д., Захарченко Т.Г. Енциклопедичний довідник майбутнього адвоката : у 2 ч. Київ : Ін Юре, 2008. Ч. 1. 616 с.

7. Джуська А.В. Конституційне право людини на професійну правничу допомогу в Україні : дис. ... канд. юрид. наук: 12.00.02. Київ, 2018. 271 с.

8. Псковская судная грамота. Российское законодательство $X-X X$ веков. Законодательство Древней Руси. Москва : Юрид. лит., 1984. Т. 1, 432 с.

9. Рагулин А.В. Общие положения учения о профессиональной защите по уголовным делам. Москва, 2008. 312 с.

10. Святоцький О.Д., Михеєнко М.М. Адвокатура України. Київ, 1997. 224 с.

11. Борисенок С. Утворення професійної адвокатури в Литовсько-Руській державі. Праці Комісії для вивчення історії західноруського та українського права. Київ, 1927. Вип. 3. С. 83-149.

12. Гловацький І.Ю. Діяльність адвоката-захисника у кримінальному процесі : навч. посіб. Київ : Атіка, 2003. 352 с.

13. Басецкий И.И., Василевская В.Л. Защитник в уголовном процессе. Минск, 2001. 300 с.

14. Історія адвокатури України / редкол.: В. В. Медведчук (голова) та ін. 2-е вид. Київ : СДМ - Студіо, 2002. 286 с.

15. Вийшла друком нова монографія «Адвокати у судочинстві ранньомодерної держави Гетьманщини». URL : http://unba.org.ua/ news/print/2564-vijshla-drukom-nova-monografiyaadvokati-u-sudochinstvi-rann-omodernoi-derzhavi-get-manshini.html (дата звернення: 13.04.2019).

16. Василенко М. «Права, по которым судится малороссийский народ» як джерело державного права України XVIII ст. Ювілейний збірник ВУАН на пошану академіка Грушевського. Київ, 1928. Ч.1. С. 245-253. 
17. Яковлів А. Український кодекс 1743 року «Права, по которым судится малороссийский народ»: Його історія, джерела та систематичний виклад змісту. Записки Наукового товариства ім. Т.Г. Шевченка. Праиі Історично-філософічної секиії. Мюнхен : Заграва, 1949. 211 с.

18. Кожевников М.В. Советская адвокатура. Москва : Юрид. изд-во НКЮ СССР, 1939. С. 15.

19. Грудцына Л.Ю. 140 лет российской адвокатуре. URL : htpp://www.ludmilagr.ru (дата звернення: 13.04.2019).

20. Гончаренко С.В. Проблеми надання безоплатної правової допомоги. Короткий огляд новітніх тенденцій. Адвокат. 2011. № 11(134). С. 12-16.

21. Буробин В.Н. Адвокатская деятельность: учебн.-практ. пособие, 2-е изд, перераб и доп. Москва : ИКФ «ЭКМОС», 2003. 623 с.

22. Сміх В.В. Кримінальна відповідальність за порушення права особи на правову допомогу : монографія. Київ, 2012. 200 с.

23. Стецовский Ю.И., Мирзоев Г.Б. Профессиональный долг адвоката и его статус : монография. Москва : ЮНИТИ-ДАНА, 2003. С. 104.

24. О реорганизации коллегий защитников: постановление коллегии Наркомата юстиции УССР от 12.09.1928 г. Вестник советской юстищии. 1928. № 2 (126). С. 609.

25. Положение об адвокатуре СССР : утв. постановлением Совета Народных Комиссаров Союза ССР от 16.08.1939 г. № 1219. URL : http://www.libussr.ru/doc_ussr/ ussr4198.htm (дата звернення: 14.04.2019).

26. Про судоустрій Української РСР: Закон УРСР від 30.06 .1960 р. (Із змінами і доповненнями за станом на 15.02.1975 р.). Київ : Політвидав України, 1975. 19 с.

27. Уголовно-процессуальный кодекс УССР : Закон УCСР от 28.12.1960 г. URL : http://pravoved.in.ua/section-kodeks/79-upku.html (дата звернення 12.04.2019).

28. Цивільний процесуальний кодекс УРСР : Закон УРСР від 18.07.1963 p. URL : https://zakon.rada.gov.ua/laws/show/1501-06 (дата звернення 13.04.2019).

29. Про затвердження Положення про оплату праці адвокатів в Українській РСР та Інструкції про порядок оплати юридичної допомоги, яка надається адвокатами громадянам, підприємствам, установам, радгоспам, колгоспам та іншим організаціям Української РСР : постанова Ради Міністрів УРСР від 08.12.1965 p. № 1178. URL : http:// search.ligazakon.ua/1_doc2.nsf/ link1/KP651178.html (дата звернення: 13.04.2019).

30. Конституція УРСР від 20.04.1978 p. URL : http://zakon.rada.gov.ua/laws/show/888-09 (дата звернення: 13.04.2019).

31. Про затвердження Положення про адвокатуру Української РСР : Закон УРСР від 31.10.1980 p. URL : http://search.ligazakon.ua/1_doc2.nsf/link1/T801050.html (дата звернення: 14.04.2019).

32. Про адвокатуру : Закон України від 19.12.1992 p. URL : https://zakon.rada.gov.ua/go/ 2887-12 (дата звернення: 12.04.2019).

33. Конституція України від 28.06.1996 p. URL : https://zakon.rada.gov.ua/laws/show/ $254 \% \mathrm{D} 0 \% \mathrm{BA} / 96-\% \mathrm{D} 0 \% \mathrm{~B} 2 \% \mathrm{D} 1 \% 80$ (дата звернення: 15.04.2019).

34. Про безоплатну правову допомогу : Закон України від 02.06.2011 p. URL : https://zakon. rada.gov.ua/go/3460-17 (дата звернення: 15.04.2019).

35. Про схвалення Концепції Державної цільової програми формування системи безоплатної правової допомоги на 2013-2017 роки: розпорядження Кабінету Міністрів України від 04.07.2012 p. № 435-p. URL : https://zakon.rada.gov.ua/go/435-2012-\%D1\%80 (дата звернення: 15.04.2019).

36. Про затвердження Державної цільової програми формування системи безоплатної правової допомоги на 2013-2017 роки: постанова Кабінету Міністрів України від 13.02.2013 р. № 394. URL : https://zakon.rada.gov.ua/go/394-2013-\%D0\%BF (дата звернення: 15.04.2019).

37. Про адвокатуру та адвокатську діяльність : Закон України від 05.07.2012 p. URL : https://zakon.rada.gov.ua/laws/show/5076-17 (дата звернення: 14.04.2019).

38. Про внесення змін до Конституції України (щодо правосуддя) : Закон України від 02.06.2016 p. URL : https://zakon. rada.gov.ua/laws/show/1401-19 (дата звернення: 15.04.2019).

39. Рішення Конституційного Суду України у справі за конституційним зверненням громадянина Солдатова Г.І. щодо офіційного тлумачення положень статті 59 Конституції України, статті 44 Кримінально-процесуального кодексу України, статей 268, 271 Кодексу України про адміністративні правопорушення (справа про право вільного вибору захисника) від 16.11.2000 р. № 13-рп/2000. URL: https://zakon.rada.gov.ua/laws/ show/v013p710-00 (дата звернення: 16.04.2019). 
40. Рішення Конституційного Суду України у справі за конституційним зверненням громадянина Голованя І.В. щодо офіційного тлумачення положень статті 59 Конституції України (справа про право на правову допомогу) від 30.09.2009 p. № 23-рп/2009. URL : https://zakon. rada. gov.ua/laws/show/v023p710-09 (дата звернення: 16.04.2019).

41. Рішення Конституційного Суду України у справі за конституційним зверненням Приватного малого підприємства - фірми «Максима» щодо офіційного тлумачення положень частини першої статті 59 Конституції України, частини першої статті 44 Господарського процесуального кодексу України (справа про відшкодування витрат на юридичні послуги у господарському судочинстві) від 11.07.2003 р. № 6-pп/2013. URL : https://zakon.rada.gov.ua/laws/show/v006p710-13 (дата звернення: 16.04.2019).

42. Про внесення змін до Господарського процесуального кодексу України, Цивільного процесуального кодексу України, Кодексу адміністративного судочинства України та інших законодавчих актів : Закон України від 03.10.2017 p. URL : https://zakon.rada.gov.ua/laws/show/2147-19 (дата звернення: 16.04.2019).

УДК 340.1

DOI https://doi.org/10.32844/2618-1258.2019.3-1.10

CMIPHOBA B.B.

\section{ПРОЦЕС СТАНОВЛЕННЯ Й РОЗВИТКУ ІНСТИТУТУ ПРИСЯЖНИХ НА ТЕРИТОРІЇ УКРАЇНИ ПІСЛЯ СУДОВОЇ РЕФОРМИ 1864 РОКУ}

Стаття присвячена аналізу розвитку інституту народного представництва під час здійснення правосуддя в цивільному судочинстві України після прийняття судових статутів 1864 року, висвітленню основних проблем, що виникали в процесі запровадження суду присяжних у радянській і незалежній Україні. Визначено, що активні реформи судової системи спонукають законодавця до вибору більш ефективної форми суду присяжних, про що свідчать законодавчі ініціативи в парламенті. Так, у Законопроекті «Про внесення змін до Кримінального процесуального кодексу України, Закону України «Про судоустрій і статус суддів» щодо удосконалення функціонування суду присяжних в Україні» від 21.08.2017 № 7022-1 пропонувалося запровадити в Україні класичну форму суду присяжних, яка б складалася з 12 основних присяжних і 12 додаткових. Передбачалося, що такий суд присяжних буде вирішувати «питання факту», а «питання права» будуть вирішуватися професійними суддями. 3'ясовано, що запровадження інституту присяжних на території України пов'язують із судовою реформою 1864 року. Аналізуючи цю реформу, можна дійти висновку, що суд присяжних був своєрідною шоковою терапією, запозичений із системи західного правосуддя. Але такий суд присяжних виявився занадто м'яким у винесенні обвинувальних рішень, що разом зі значною політизацією судових процесів призвело до обмеження кількості справ за участю присяжних, кризи інституту присяжних загалом i, як наслідок, повного скасування цього інституту в 1917 році. Зроблено висновок, що з моменту створення інституту народного представництва під час здійснення правосуддя характерним було його пристосування до політичних та економічних викликів. Брак самостійності й незалежності присяжних призвів до виключно декларативного існування цього інституту в цивільному судочинстві України. Досвід історичного розвитку інституту присяжних має бути врахований під час побудови нової моделі, яка, враховуючи реформи та виклики сьогодення, стане ефективним інструментом народного контролю і зниження корупційних ризиків під час прийняття судових рішень.

Ключові слова: присяжні, інститут присяжних, народні засідателі, суд присяжних.

СМІРНОВА В.В. - аспірантка кафедри цивільного права і процесу (Національна академія внутрішніх справ) 